УДК 355.45(474.5)"193"

ЙОКУБАУСКАС В.

htttp//orcid.org/0000-0002-5578-4880

https://doi.org/10.33577/2313-5603.33.2020.140-159

\title{
ТЕРИТОРІАЛЬНА ОБОРОНА У ЛИТВІ В КІНЦІ 30-х РОКІВ ХХ СТОЛІТТЯ
}

У статті проаналізовано проблему територіальної оборони у Литві в період між двома світовими війнами, у контексті національної безпеки Литви. Литва отримала багатий досвід партизанського спротиву в часи Війни за незалежність 1919 - 1920 pp. і конфлікту з Польщею у 1921 - 1923 рр. Завдячуючи такому досвіду, в країні була розроблена доволі унікальна система територіальної оборони, основою якої стала структура Союзу стрільців Литви (далі - ССЛ). На випадок війни організовані загони стрільців-партизан мали діяти поруч з частинами регулярної армії. Воєнна доктрина Литви спиралася на синергію дій регулярних військ, формувань територіальної оборони і допомоги союзників потужних держав регіону.

Ключові слова: армія Литви, міжвоєнні роки, Союз стрільців Литви, територіальна оборона, територіальне прикриття, територіальний опір, територіальна охорона, партизани.

Постановка проблеми та ї̈ актуальність. У міжвоєнні роки Литовська держава зіштовхнулася 3 широким колом загроз національній безпеці, серед них: економічні санкції, втручання інших країн у внутрішні справи Литви, деструктивна діяльність «п'ятої колони», територіальні конфлікти з Польщею і Німеччиною і т. п. 3-поміж основних була і загроза прямих військових дій в разі вторгнення Польщі або Німеччини, а з кінця 1939 року і СРСР (оскільки до цього, з 1920 до 1939 р. Литва не мала спільного кордону 3 радянською державою). У разі війни дисбаланс сил Литви і евентуальних противників був очевидний (наприклад, населення Литви складало 2,5 млн, Польщі - 35 млн, у Німеччині проживало близько 70 млн, в СРСР - 170 млн). У такій ситуацій армія Литви, маючи на меті, в першу чергу, зберегти боєздатність та уникнути розгромної поразки у випадку першого нищівного удару противника, шукала "незвичних" рішень. Командування армії Литви дотримувалося думки, що війна в Свропі буде глобальною і Литва буде воювати не одна, а 3 союзниками, серед

Йокубаускас Вітаутас, доктор гуманітарних наук, старший науковий співробітник Інституту історії та археології Балтійського регіону при Клайпедському університеті (Литовська Республіка).

(C) Йокубаускас В., 2020 
яких будуть і найбільші держави Європи. Успіх литовських збройних сил буде залежати від військових успіхів великих союзників. Основними прикладами, які підтверджували цю теорію, для армії Литви були Сербія та Бельгія під час Першої світової війни, литовські офіцери у секретних документах посилалися саме на досвід цих двох країн.

Необхідно відзначити, що у міжвоєнні роки Литовська держава відправила на навчання до військових академій Західної Європи загалом близько 150 офіцерів. У якості основних країн, де проходили навчання литовські військові, в основному обирали Францію, також Бельгію і Чехословаччину - тобто, країни, які були під прямим впливом французької військової школи.

Важливим досвідом для планування оборони держави була не тільки Перша світова війна, а також і війни за незалежність Литви 1919-1920 рр.: збройне протистояння з Радянською Росією, збройний конфлікт з Російською Західною добровольчою армією (під командуванням Павла Бермондта-Авалова), військова кампанія проти Польщі (Lesčius, 2004; Vareikis, 1999; 2013). У ході визвольних змагань литовського народу активну участь брали загони литовських партизан. За приблизними підрахунками у цьому партизанському русі брали участь близько 15 тисяч осіб.

Ще майже три роки (1921-1923 рр.) бойові дії між литовськими та польськими підрозділами в нейтральній, демілітаризованій зоні (що виникла у результаті розведення сил обох країн після закінчення «гарячої фази» конфлікту, у листопаді 1920 р.) велися силами партизанських загонів.

Як відомо, попри те, що у результаті цих воєн Литва зуміла захистити відроджену у 1918 р. незалежність, держава тимчасово втратила свою історичну столицю Вільнюс, і два десятиліття жила в умовах замороженого військового конфлікту з Варшавою, 3 перестрілками на "кордоні" (Литва демаркацію не визнала) між прикордонниками, а литовське суспільство всі ці роки жило 3 гаслом - «ми без Вільнюса не заспокоїмося» (лит. mes be Vilniaus nenurimsim). Цей досвід звичайно не міг не вплинути на концепцію оборони Литви.

Аналіз попередніх досліджень та публікащій. У литовській історіографії опрацьовувалася тема оборони силами військових у міжвоєнні роки. Результати своїх досліджень опублікували кілька авторів (Kasparavičius, Mieliauskas, 1998; Lesčius, 2013; 
Žalys, 1989). Можна зазначити також і ряд публікацій, що належать перу автора даної статті (Jokubauskas, 2009; 2011; 2012a; 2012b; 2014a; 2019; Йокубаускас, 2012). Проте питання територіальної оборони не піднімалося, хоча для Литви та іiі збройних сил це вельми актуальна проблема.

Говорячи про відображеність зазначеної нами проблеми, відмітимо, загалом, вкрай незначну представленість в українському науковому доробку праць, що стосувалися б історії міжвоєнної Литовської держави. Ще більш локалізоване питання - історія литовських збройних сил даного періоду, поки не висвітлено на рівні достатньому хоча б для розуміння загальних обрисів процесів, які відбувалися у ході розбудови армії Литви в період між Війною за незалежність та радянським вторгненням у 1940 р. Питання литовського досвіду використання парамілітарних формувань у якості військ територіальної оборони, в умовах творення національної воєнної доктрини, в українській історіографії не відображене досі.

Історія литовських збройних сил і парамілітарних формувань опосередковано подавалася у ряді праць, та виключно у контексті проблематики стосунків між українським визвольним рухом і Литвою протягом 1920-1930-х рр. До цього пласту належать праці дослідників повоєнної епохи, діячів українського визвольного руху, активістів еміграції, зокрема зазначимо роботи В. Мартинця (Мартинець, 1949), П. Мірчука (Мірчук, 1968), О. Думіна (Dumin, 1974). Також ця умовна категорія може бути представлена дослідженнями, що побачили світ вже після відновлення незалежності України, це розвідки А. Кентія (Кентій, 1998), О. Кучерука (Кучерук, 2000, 2019). Окремо відзначимо наявність робіт науково-популярного характеру, які, тим не менш, висвітлюють бойовий шлях армії Литви в роки литовських визвольних змагань і частково в епоху між світовими війнами (Гоменюк, 2017; Петрик, 2018).

Водночас, проблема побудови системи оборони, є одним 3 актуальних питань, тим паче в умовах збройного конфлікту та «гібридних викликів», які постали перед Українською державою та іiї військом у 2014 р. Вони залишаються наявними і сьогодні. Не дивно, що питання побудови ефективної системи територіальної оборони відображається у працях сучасних українських дослідників. Так, різні сегменти даного багатоелементного поля 
бачимо у роботах Г. Єфімова (Єфімов, 2004), Ф. Саганюка i В. Гуменюка (Саганюк, Гуменюк, 2011), І. Романченка і В.Фролова (Романченко, Фролов 2009), А. Михайлова (Михайлов, 2013), Є. Панкратова та В. Сфіменко (Панкратов, Сфіменко, 2015), С. Янюка (Янюк, 2019) та інших. Висвітлені вони і у грунтовних дисертаційних дослідженнях, зокрема, у працях В. Палія (Палій, 2006 ) та В. Фролова (Фролов, 2010), а також дослідженнях ряду інших науковців.

У цьому дослідженні ми спиралися на джерела, що зберігаються у Центральному державному архіві Литви у Вільнюсі. Базовим став пласт матеріалів двох фондів - ф. 929 Штаб литовської армії (лит. Lietuvos kariuomenès štabas) та ф. 561- Союзу стрільців Литви (лит. Lietuvos šauliu sajunga). Архівні документи, що збереглися, дозволяють нам доволі точно розкрити воєнні плани Литви, а також відновити причинно-наслідковий ланцюг у даному контексті. Наше дослідження проводилося на основі документів плану оборонного характеру (детальніше: Jokubauskas, 2009) - плану № 1 «Німеччина» (лит. «V» - Vokietija), тому що оперативний (Jokubauskas, Tamkvaitis, 2018) план № 3 «Польща» (лит. «L»-Lenkija) після 1939 р. не був більше актуальним і на його базисі протягом 1939-1940 рр. був складений план «Червоні /Схід/Росія*» (лит. «R»-Raudonieji / Rytai / Rusija), що призначався на випадок протистояння 3 Радянським Союзом (детальніше: Jokubauskas, 2014a: 476-516; 2014b; 2019: 307-326). Втім більшість документів цього плану було знищено литовськими офіцерами у червні 1940 р., що зробило детальний аналіз неможливим. Між тим усі документи плану № 1 «Німеччина» збереглися, що дозволяе нам детально аналізувати систему територіальної оборони Литви 1939-1940 рр. у контексті загальної оборонної стратегії невеликої країни.

Мета та завдання дослідження. У статті будуть проаналізовані питання: функціонування системи територіальної оборони Литви у кінці $30-$ - років XX століття; структур цільової відповідальності, на які покладалося здійснення функції територіальної оборони. Аналіз проблеми на основі архівних даних допоможе зрозуміти, яким чином невелика за територією держава планувала інтегрувати територіальні підрозділи у загальну державну систему

${ }^{*}$ Наразі немає точного розшифрування літери «R». 
оборони наряду з регулярними збройними силами. У документах підкреслювалося, що такий концепт - унікальна система, створена литовською армією. Слід зазначити, що питання створення ефективної системи територіальної оборони залишається актуальним у XXI ст., особливо у випадках зіткнення держав, що мають різні потужності. Стратегія, побудована на принципі стримування ворога, а значить, і виграшу часу, а також тактика, заснована на контрмобільності, на основі дій партизанського характеру, при задіянні інженерних заходів, характерна для менш сильних у військовому відношенні держав. Так, наприклад, литовська армія, сподівалася призупинити наступальні дії великих механізованих танкових з'єднань противника у перші дві доби 3 початку бойових дій. Пізніше планувалося, що ворог змушений буде перекинути частину наявних сил для боротьби із загонами литовських партизанів та для охорони власного тилу. Відзначимо, ця проблема є характерною і для сучасних армій.

Виклад основного матеріалу. Союз стрільців Литви: структура та чисельність

Союз стрільців Литви був заснований у червні 1919 року 3 метою оборони мирного населення від насильницьких дій з боку бійців Робітничо-Селянської Червоної Армії, польських військ, Західної добровольчої армії та банд мародерів. ССЛ формувався на основі партизанських загонів, що виникали спонтанно у різних місцевостях країни, у якості руху опору різноманітним загарбникам. У ході воєн за незалежність Литви в партизанському русі брало участь близько $0,75 \%$ від загальної чисельності населення Литви (Jokubauskas, 2011: 54). До самої ліквідації ССЛ, 11 липня 1940 р., основними елементами в структурі Союзу були окремі взводи і роти, які функціонували автономно, об'єднуючи членів Союзу в окремих селищах, містечках, а в містах - у формі осередків на заводах, у кооперативах, державних установах, а також стрілецьких об'єднань міських кварталів.

Таким чином, ССЛ являв собою автономну територіальну, мережеву структуру. Членство в Союзі було добровільним і підтримувалося особистими патріотичними мотивами вступників. Важливою особливістю ССЛ було те, що своєї життєздатності він міг не втрачати навіть після ліквідації центральних штабів, або після формального закриття самої організації. Взводи і роти стрільців, до яких здебільшого входили люди, що жили по сусідству, 
були близько знайомі або навіть родичами (останній аспект особливо типовий для сільської місцевості), могли, у випадку необхідності, швидко координувати дії між собою та з іншими взводами, організовувати і чинити збройний опір, навіть в умовах захоплення території ворожими військами.

Діючи за територіальним принципом, стрільці кожного повіту належали до окремої військової частини - територіального формування (лит. Rinktine) ${ }^{*}$, яке саме по собі не було військовотактичною частиною, а лише адміністративною одиницею. Тому виконання військових завдань покладалося не на територіальні формування, а на окремі роти і взводи Союзу стрільців. У 1940 р. таких формувань нараховувалося всього 22, одне територіальне формування - залізничне XXII, діяло на всій території країни. У складі всіх територіальних формувань налічувалося близько 1200 взводів, але в містах вони іноді були об'єднані у роти. Таким чином, окремих підрозділів було менше - 872 (Lietuvos šauliu sajunga valstybés, 2005: 13). Взводи часто розташовувалися порівняно віддалено і не були численними. У 1940 р. у ССЛ входило близько 88000 осіб (приблизно 3,5\% населення країни), 3 них 48000 складали стройові стрільці (бійці), а решта - нестройові члени Союзу, жінки, почесні члени ССЛ, учні та кандидати на вступ.

\section{Концепція територіальної оборони}

На основі джерел (документів армії Литви) констатуємо, що територіальна оборона може трактуватися як симбіоз семи елементів: 1) підрозділ діє на певній території, знаходячись у взаємодії з сусідніми загонами; 2) в опорі бере участь або принаймні сприяє і підтримує його, місцеве населення; 3) до опору залучаються представники місцевої цивільної влади; 4) загони бійців формуються за місцевим принципом 3 тутешніх жителів; 5) при здійсненні опору противнику загони використовують партизанську тактику бойових дій; 6) опір ведеться на території, яка зайнята ворогом, і підрозділи тероборони ведуть бойові дії проти ворога, не здійснюючи відступу разом з регулярними частинами; 7) ліквідація противником точок опору однієї з ділянок оборони

* Дослівний переклад слова rinktine українською - «збірна», але за змістом логічніше цей термін перекласти як територіальне формування. 
не має прямого впливу на продовженні бойових дій в інших областях та не ліквідовує загальної мережі опору.

Таким чином, автономність, здатність вести тривалий опір окупантам, наявність зв'язку 3 місцевим населенням і цивільною владою становили найважливіші елементи здійснення територіальної оборони. Основна мета сил територіальної оборони полягала не у тому, щоб остаточно перемогти ворога у відкритому протистоянні, але в тому, щоб не допустити програшу війни через припинення спротиву. Здатність вижити і продовжувати боротися вже може вважатися перемогою, цей факт спроможний завадити супротивнику виграти, що може призвести до nатової cumyaųï, використовуючи шахову термінологію.

У міжвоєнний період (1920-1930-ті роки) у Литві на територіальні війська покладалося вирішення таких основних проблеми сприяння інтенсифікації оборони країни, як:

1) мобілізація резервістів і комплектація військових частин;

2) територіальна оборона, ефективна реалізація принципів якої полягала у наступних аспектах:

а) територіальне прикриття основних сил у період їх мобілізації та концентрації; руйнування інфраструктури та стримування просування сил противника;

б) територіальний опір - активна збройна або беззбройна боротьба, за умови сприяння з боку місцевого, лояльного населення на територіях, зайнятих ворогом. Конкретні дії могли полягати у знищенні живої сили противника, важливих об'єктів, ресурсів, ліній зв'язку та інфраструктури ворога в цілому;

в) територіальна охорона - захист і охорона інфраструктури та інших важливих об'єктів у тилу литовських регулярних військ, а також допомога поліції у підтримці цивільного порядку, крім того - боротьба 3 ворожими силами, колаборантами i диверсантами.

У директиві штабу Литовської армій «ШАДІР» від 1938 року про призначення ССЛ вказувалося, що в разі війни, в першу чергу, частина стрільців повинна залишатися в тилу ворога i вести там партизанську війну (LCVA 3: 12).

Такої лінії дій штаб литовських збройних сил продовжував дотримуватися і у 1940 р. Партизани мали діяти в добре знайомій місцевості, невеликими загонами або навіть індивідуально. 
Їх повинні були оснастити легким озброєнням, а оперативні дії загонів проводитися у лісовій та заболоченій місцевості. Ці вказівки повторювалися і в статутах піхоти та кавалерії армії Литви. Для стрільців були видані спеціальні книги з тактичними рекомендаціями - «Партизанська тактика» та «Особливості тактики стрільців», в яких аналізувалася партизанська тактика (Jokubauskas, 2011: 58-61). У разі раптового нападу ворога, стрільцям слід було діяти самостійно, без додаткових наказів центральної влади (LCVA 3: 31).

Один 3 литовських військових теоретиків, викладач військової підготовки, майор генерального штабу Вітаутас Булвічіус напередодні Другої світової війни, у 1939 р., у своїй книзі відобразив загальну перспективу ведення війни недалекого майбутнього, 3 точки зору литовських армійських кіл. Поряд з використанням бойових можливостей авіації і танків автор акцентував на важливості партизанських дій та провів аналіз гіпотетичних військових дій в умовах сучасної йому Литви і ясно визначив провідну роль стрільців у ініціативі та веденні партизанської війни у разі зовнішнього вторгнення (Bulvičius, 1994: 97, 145).

Одна із останніх вказівок, яку стрільці отримали від штабу армії Литви, датується квітнем 1940 р. Так, у директиві про застосування ССЛ у разі війни писалося, що Німеччина після закінчення військового конфлікту на Заході може напасти на Литву, в такому випадку стрільцям слід було прикривати мобілізацію, відступаючи, знищувати інфраструктуру, захищати важливі об'єкти у тилу. Кожен стрілець, що залишився в запіллі ворога, повинен був вести партизанську війну (LCVA 1: 44).

Для цього в ССЛ була висунута мета, популяризувати рух стрільців в Литві з гаслом «sušaulinti Lietuvą» *, який закликав до масового вступу у союз і наближення до втілення ідеалу збройної і патріотично налаштованої нації (Vygantas, 1933: 302).

На початку 1940 року були розроблені плани поділу прикордонних повітів на райони - ділянки - клітини (Див. картосхема №1). Основними одиницями цієї системи були ділянки, що створювалися на основі територіальної мережі загонів і рот

\footnotetext{
* Буквальний переклад українською неможливий, але за змістом гасло означає «мілітаризувати Литву», що полягало у декларуванні прагнення, щоб ССЛ
} 
стрільців (приклад цього - бджолині соти). Для зручності координації дій підрозділів територіального прикриття всі ділянки були об'єднані по кілька, в райони. А кожна ділянка поділялася на кілька клітин - зон тактичних завдань. За планом, територія ділянок у середньому становила 70 км² $^{2}$ населенням близько 2500 осіб у кожній, з них - до 1000 осіб працездатного віку. За сприяння мирного населення стрільці повинні були організовувати та управляти руйнуванням інфраструктури, знищувати мости, перекопувати дороги або завалювати їх деревами (конкретний план дій територіальних загонів Литви, на прикладі місцевості поблизу кордону з Німеччиною, можна побачити на топографічній мапі - додаток 1).

При появі ворога мирне населення повинно було повернутися до своїх хуторів, а озброєні стрільці залишалися б поблизу створених загороджень і мали влаштовувати засідки. Стрільціпартизани мали вести обстріл противника 3 максимально безпечних позицій, але не вступати в інтенсивний бій. При наступі ворога, сили якого перевищували сили партизан, останні повинні були відступити та зібратися у заздалегідь умовленому місці. Там проводилася підготовка до нової засідки у зручному місці. Виконавши всі завдання на своїй ділянці, стрільцям-партизанам слід було приєднається до загону сусідньої ділянки, таким чином підсилюючи територіальне прикриття. Втім, підійшовши до рубежів, оборону яких здійснювали регулярні частини литовських збройних сил, стрільці-партизани залишалися б у тилу ворога, та переходили до організації та здійснення територіального опору.

При спробі знайти зарубіжні аналоги подібної тактики ділянок і використання малих підрозділів проти великих механізованих частин противника на своїй території, за підтримки місцевого населення, ми прийшли до висновку, що жодна з великих країн Європи за подібних умов воювати не збиралася. Говорячи про пошук прикладів аналогічного досвіду так званих «малих країн», зазначимо, що у даному контексті вони традиційно використовують набутки великих держав. Таким чином, зазначимо, що більш актуальним при створенні власної системи територіальної оборони видається використання вітчизняного досвіду з урахуванням місцевих умов (LCVA 4: 8-10; LCVA 11: 2-19, 23; LCVA 6: 3-4; LCVA 9: 2-9). 
Базова структура районів, ділянок та клітин *

\section{ПРИНЦИПОВА СИСТЕМА ДІЛЯНОК}

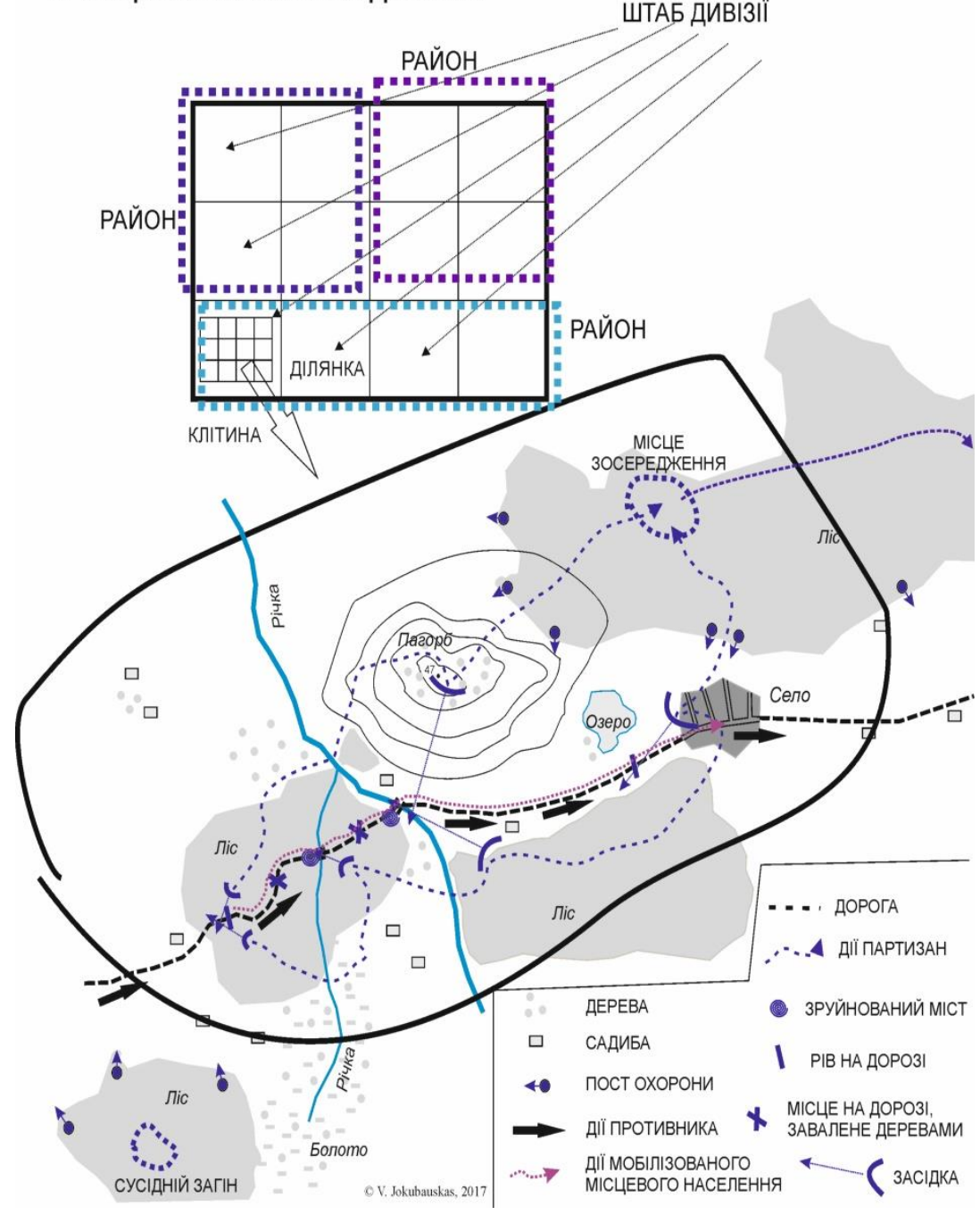

* У картосхемі №1 поданий принцип структури територій і дій стрільцівпартизан, але не ситуація конкретної місцевості. 
Поруч із загонами стрільців-партизанів мали оперувати декілька груп прикриття, сформованих із регулярних частин. На 1940 р. діяло 5 таких груп у місцевостях: Маріямполєс, Расейняй, Таурагес, Варна і Плунгес. Також весь кордон з Німеччиною, у разі війни, повинні були прикривати 7 батальйонів прикордонної оборони (БПО), які формувалися на основі прикордонної поліції, включаючи місцевих стрільців. У разі необхідності, за умови нестачі людського ресурсу, до загонів могли бути закликані резервісти, у віці до 35 років. У лінії кількох кілометрів від кордону повинні були діяти тільки підрозділи БПО (LCVA 10: 2-10; LCVA 7: 1-6; LCVA 6: 7-17; Vaičenonis, 2002).

Таким чином, командування литовської армії сподівалося виграти час для мобілізації і концентрації регулярних частин (загалом розраховували на більш ніж 125000 офіцерів і солдатів, зведених у 5 піхотних дивізій і певну кількість окремих частин піхоти, кавалерії, артилерії, танків, авіації і т. п.). Задля мобілізації армії Литви потрібно було 20-30 годин, для концентрації ще 2-3 доби (LCVA 5: 2-41; LCVA 8: 1-25; LCVA 2: 8-10).

Висновки. Територіальні сили Литви мали здійснювати прикриття та підтримку регулярних частин, оскільки саме «територіалам», у разі війни, випадало забезпечувати охорону тилу. Партизанськими діями в тилу ворога вони повинні були відтягнути з фронту частину його сил, і таким чином знизити тиск на регулярні частини литовської армії (Див. картосхему №2). За концепцією оборони країни збройні сили Литви планували вести маневрену війну - зупиняти ворога, захищаючись на широких ділянках фронту, уникаючи вирішальних боїв. За умови посиленого тиску ворога планувалося відступати по заздалегідь передбачених напрямках. 


\section{План оборони Литви на початку 1940 р. за оперативним планом «В» (лит. , $V^{66}$ Vokietija - Німеччина) *}

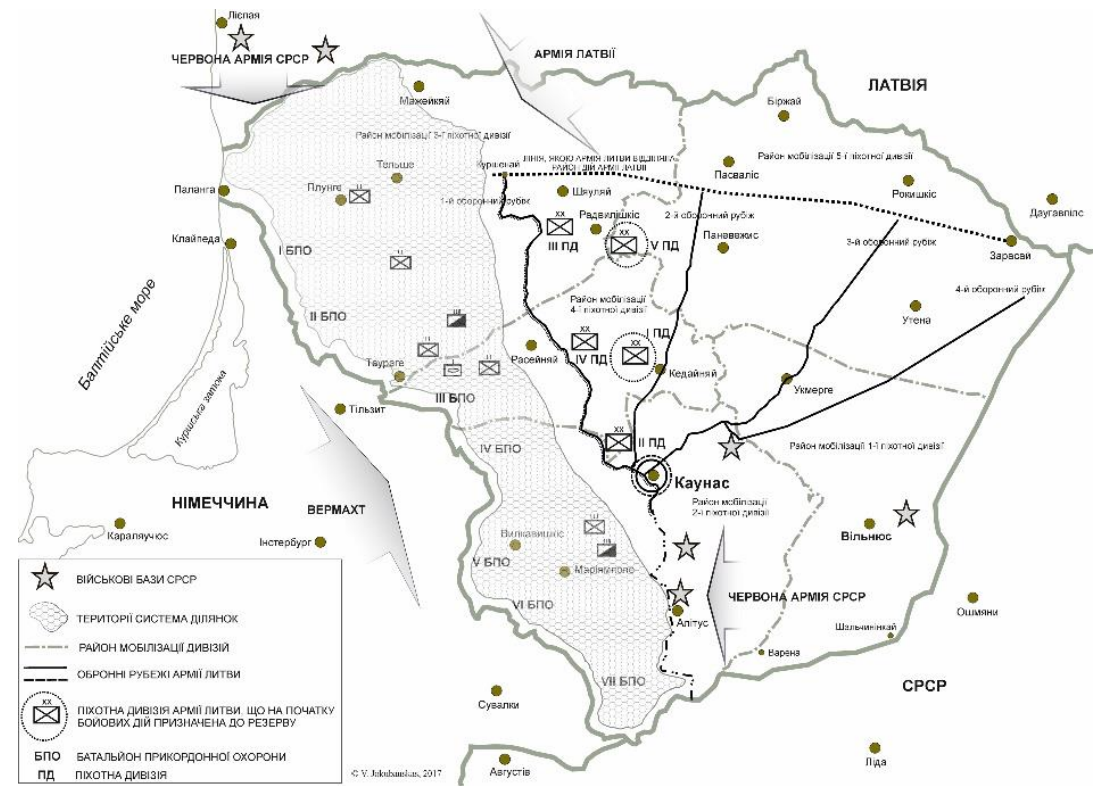

Політичні і військові еліти Литви сподівалися, що війна в Європі буде глобальною, і країна буде боротися не на самоті, а у складі великої коаліції (як Бельгія або Сербія під час Першої світової війни). Однак, зіткнувшись 3 агресією Литва, в реальності, не дочекалася підтримки ззовні. У 1940 р. правлячі еліти обрали шлях політичної капітуляції. Концепції територіальної оборони і партизанського опору на практиці були перевірені вже в умовах окупації - в 1941 р. і у 1944-1953 рр., вони діяли навіть після капітуляції литовського державного організму та анексії держави.

* На початку 1940 р. існував і план «Р» (лит. " $R$ "), призначений для оборони країни у випадку агресії з боку СРСР. Більшість документів, що стосувалися цього плану, були знищені напередодні радянської окупації. 


\section{Додаток 1 (топографічна мапа)}

Мапа прикордонних з Німеччиною територій (Ендріявас, Вєівірженай, Швекшна (лит. Endriejavas, Veiviržėnai ir Švèkšna), містечка, розташовані на відстані приблизно у 40-50 км на схід і південний схід від міста Клайпеди), перша половина 1940 р.

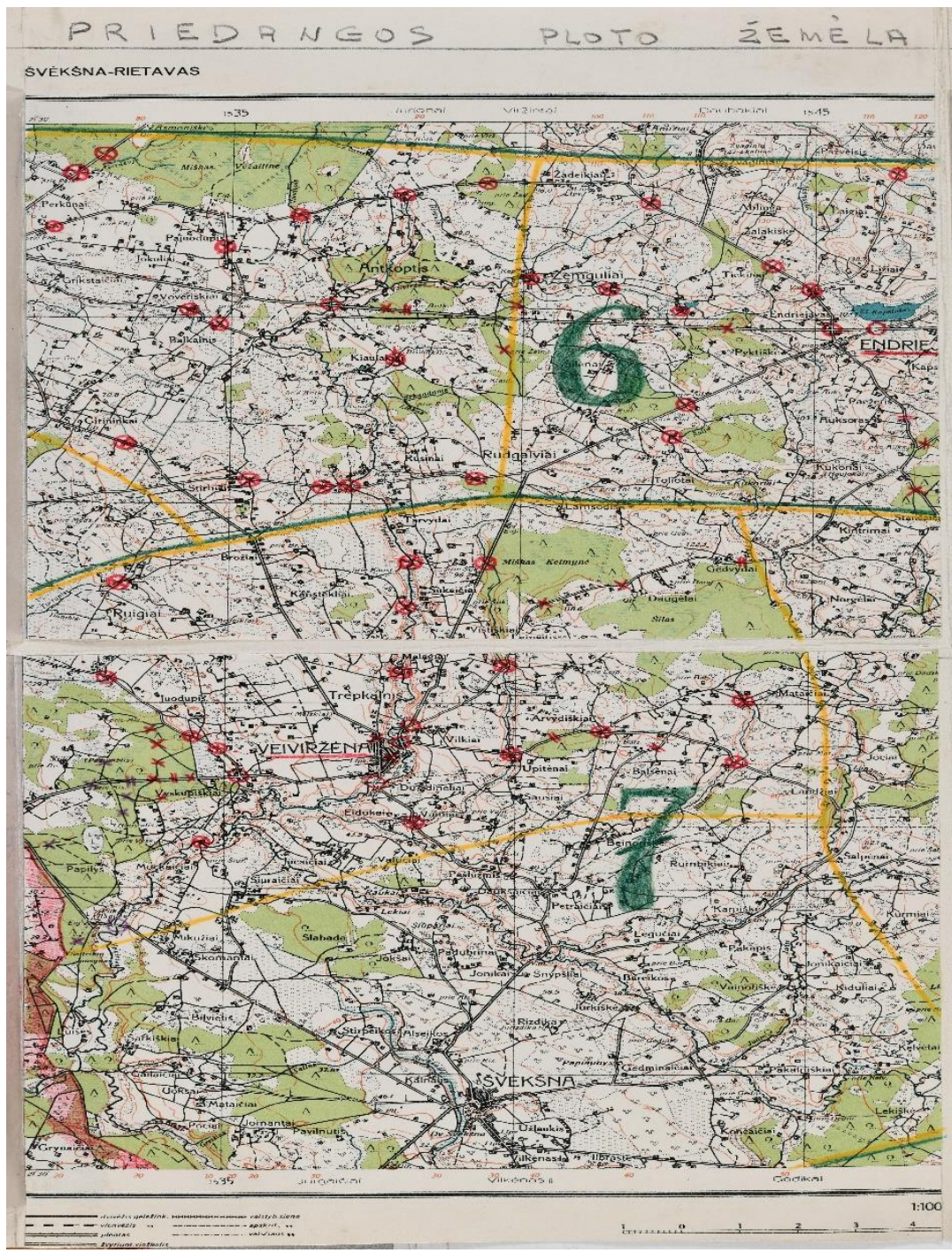




\section{Умовні позначення:}

міст, що мав бути зруйнований бійцями територіальних загонів за допомогою місцевого населення;

міст, що мав бути підпалений територіальними загонами за допомогою місцевого населення;

об'єкти (мости, перехрестя доріг і т.п.), що мали підриватися територіальними загонами за допомогою місцевого населення;

|| місце на дорозі, що мало бути перекопане бійцями територіальних загонів за допомоги місцевого населення;

місце на дорозі, що територіальні підрозділи за допомогою місцевого населення мали загородити завалами зі зрубаних дерев.

Жовтими лініями відмічені рубежі - ділянки, а зеленими райони. Цифри 6 та 7, позначають номери районів територіальної оборони (прикриття).

У лівому краю мапи можна побачити частину червоної лінії кордону між Литвою та Німеччиною (Клайпедським краєм) 3 березня 1939 p.

\section{Використані посилання}

LCVA 1 - Lietuvos Centrinis Valstybės Archyvas (Центральний державний архів Литви). LCVA, f. 561, ap. 18, b. 187. Lietuvos šauliu sajungos mobilizacijos reikalai $1940 \mathrm{~m}$.

LCVA 2 - LCVA, f. 929, ap. 3, b. 1020. Evakuacijos planas ir ji liečias susirašinèjimas $1940 \mathrm{~m}$.

LCVA 3 - LCVA, f. 929, ap. 3, b. 1028. Šauliu panaudojimo planas III pestininku divizijoje $1939 \mathrm{~m}$.

LCVA 4 - LCVA, f. 929, ap. 3, b. 1097. Šauliu sajunga liečiąs susirašinėjimas $1940 \mathrm{~m}$

LCVA 5 - LCVA, f. 929, ap. 3, b. 1131. Mobilizacijos direktyvos $1940 \mathrm{~m}$.

LCVA 6 - LCVA, f. 929, ap. 3, b. 1153. Priedanga, II péstininku divizijos planas $1940 \mathrm{~m}$.

LCVA 7 - LCVA, f. 929, ap. 3, b. 1155. Priedanga, II péstininku divizijos planas $1940 \mathrm{~m}$.

LCVA 8 - LCVA, f. 929, ap. 5, b. 547. 1939 m. rugsejjo mènesio mobilizacijos reliacija. 
LCVA 9 - LCVA, f. 929, ap. 5, b. 587. Pasienio apsaugos dalims mobilizuoti 1940 m. direktyva.

LCVA 10 - LCVA, f. 929, ap. 5, b. 605. Susirašinèjimas pasienio apsaugos reikalu $1940 \mathrm{~m}$.

LCVA 11 - LCVA, f. 929, ap. 5, b. 608. Kariuomenès štavo III skyriaus mobilizacijos dalies susirašinèjimas $1940 \mathrm{~m}$.

Гоменюк I. (2017) Провісники Другої світової. Прикордонні конфлікти в Центрально-Східній Європі. Від розпаду імперій до Гляйвіцької провокаиії. Харків: Книжковий клуб «Клуб Сімейного Дозвілля». 352 с.

Єфімов Г. (2004) Поняття територіальної оборони складає основу обороноздатності держави. Військо України. Київ. № 5-6. С. 13-16.

Йокубаускас В. (2012) Концепция партизанской войны в Литве в 19201930-е годы. Балтийский регион, № 2 (12), с. 43-57.

Кентій А. В. (1998) Украӥнська військова організація (УВО) в 1920-1928 рр. Короткий нарис. Київ. 81 с.

Кучерук О. (2000) Останній паспорт Свгена Коновальця (до генези українськолитовських стосунків між двома світовими війнами). Пам'ять століть. № 5. С. 59-60.

Кучерук О. (2019) Литва і Україна: епізоди спільної історії. Київ: Залізний тато. $118 \mathrm{c}$.

Мартинець В. (1949) Українське підпілля. Від У.В.О. до О.У.Н. Спогади й матеріяли до передісторії та історії украӥнського організованого начіоналізму. Вінніпег: Ukrainian National Fed'n. D. E. 349 c.

Михайлов А. О. (2013. Роль та місце органів внутрішніх справ України в системі територіальній обороні держави. Труди академії, № 2 (116). С. 121-125.

Мірчук П. (1968) Нарис історії Організачії Украӥнських Начіоналістів 1920-1939. Т. 1. Мюнхен-Лондон-Нью-Йорк: Українське видавництво. 639 с.

Палій В.В. (2006) Обтрунтування завдань Збройних Сил Украйни при веденні територіальної оборони. [дис. канд. військ, наук]. Київ. 237 с.

Панкратов Є.Є., Єфіменко В.I. (2015) Територіальна оборона. Оборонний вісник. Київ. № 11. С. 12-16.

Петрик А.М. (2018) «Світло та тіні» Периої республіки: Литовська держава у 1918-1940 роках. Херсон: Гілея. 272 с.

Романченко І.С., Фролов В.С. (2009) Роль і місце територіальної оборони України в загальній системі оборони держави. Наука $і$ оборона. Київ. № 1. C. 36-39.

Саганюк Ф., Гуменюк В. (2011). Територіальна оборона: резерв обороноздатності країни. Військо Украӥни. Київ. № 6. С. 15-17.

Фролов В.С. (2010). Обтрунтування механізму щзодо визначення необхідного складу військових формувань територіальної оборони в зоні воєнного конфлікту. Київ. 191 с.

Янюк С. (2019) Територіальна оборона як протидія загрозам національній безпеці України. Актуальні проблеми державного управління. Одеса, № 1 (77). C. 94-99.

Bulvičius V. (1994) Karinis valstybès rengimas. Vilnius: Savanoriškoji krašto apsaugos tarnyba, 274 р. [перше видання, 1939]. 
Dumin O. (1974) Prawda o Ukraińskiej organizacji wojskowej. Zeszyty historyczne. Paryż. Z. 30. S. 103-137.

Jokubauskas V. (2009) Tuščias šūvis: galimybès atremti Vokietijos karinę grèsmę 1939 metais. ISTORIJA, t. LXXIII, P. 25-36.

Jokubauskas V. (2011) Žvelgiant $\mathfrak{i}$ ateitị: partizaninès kovos taktikos sklaida Lietuvoje ir jos igyvendinimas 1944-1953 m. Genocidas ir rezistencija, Nr. 1 (29), P. 51-68.

Jokubauskas V. (2012a) Lietuva ant karo slenksčio: $1939 \mathrm{~m}$. kariuomenès mobilizacija. Karo archyvas, t. XXVII, P. 276-332.

Jokubauskas V. (2012b) „Vienui vieni“: šaulių rengimas partizaniniam karui 1924-1940 m. Lietuvoje. Istorija, t. LXXXVI, P. 11-24.

Jokubauskas V. (2014a) „Mažuju kariuomeniu“" galia ir paramilitarizmas. Tarpukario Lietuvos atvejis. Klaipeda: Klaipedos universitetas. 588 p.

Jokubauskas V. (2014b) Lietuvos kariuomenès „R“ planas (1939-1940 m.). Istorija, t. XCIII, Nr. 1. P. 5-47.

Jokubauskas V., Tamkvaitis T. (2018) Du karo istorijos šaltiniai iš Lietuvos tarpukariu. In THE UNENDING WAR? THE BALTIC STATES AFTER $1918=$ NESIBAIGIANTIS KARAS? BALTIJOS ŠALYS PO 1918 METŲ, Acta Historica Universitatis Klaipedensis, vol. XXXVI. Ed. by V. Jokubauskas, V. Safronovas. Klaipeda. P. 177-242.

Jokubauskas V. (2019). NETIESIOGINIS POVEIKIS IR LIETUVOS KARINIS SAUGUMAS 1919-1940 M. Klaipeda: Druka, 368 p.

Kasparavičius A.; Mieliauskas T. (1998) Lietuvos-Lenkijos santykiai ir Lietuvos kariuomenès modernizavimas 1926-1939 metais. Karo archyvas, t. XV, p. 144-161.

Lesčius V. (2004). Lietuvos kariuomene nepriklausomybès kovose 1918-1920. Vilnius: Generolo Jono Žemaičio Lietuvos karo akademija; Vilniaus universitetas, $500 \mathrm{p}$.

Lesčius V. (2013) Lietuvos kariuomenès gynybos planai ir priemonès galimai lenkų agresijai atremti 1921-1937 m. Karo archyvas, t. XXVIII, P. 149-304.

Lietuvos šauliu sajunga valstybès ir visuomenés tarnyboje 1919-2004. (2005). Sud. V. Kavaliauskas, J. Širvinskas, S. Jegelevičius. Kaunas: Lietuvos šauliu sajungas, $312 \mathrm{p}$.

Vaičenonis J. (2002) Lietuvos šaulių sajunga valstybès gynyboje 1935-1940 m. Lietuvos šauliu sajungos istorijos fragmentai. Konferencijos pranešimu medžiaga. Red. J. Vaičenonis; S. Dovydaitis. Kaunas: Lietuvos šaulių sajunga, P. 110-119.

Vareikis V. (1999) Lietuvos šauliu sajungos politine ir karine veikla (19191923). [daktaro disertacija]. Kaunas: Vytauto Didžiojo universitetas, 145 p.

Vareikis V. (2013) Išèjimas iš K. Donelaičio gatvès: Lietuvos šaulių sajungos karinè veikla 1919 m. Kauno istorijos metraštis, t. XIII, P. 147-161.

Vygantas. (1933) Ką mums liepia dabartinè valanda. Trimitas, 1933, 20 квітня, Nr. 16, C. 301-302.

Žalys V. (1989) Dèl karinio bendradarbiavimo Baltijos antantès sistemoje (19391940 m.). Lietuvos istorijos metraštis. 1988 metai, P. 59-78. 


\section{References}

LCVA 1 - Lietuvos Centrinis Valstybès Archyvas (Lithuanian Central State Archives). LCVA, f. 561, ap. 18, b. 187. The Lithuanian Riflemen's Union mobilisation affairs, 1940

LCVA 2 - LCVA, f. 929, ap. 3, b. 1020. The Evacuation Plan and related correspondence, 1940

LCVA 3 - LCVA, f. 929, ap. 3, b. 1028. The Plan for the Use of Riflemen in the $3^{\text {rd }}$ Infantry Division, 1939

LCVA 4 - LCVA, f. 929, ap. 3, b. 1097. The correspondence pertinent to the Riflemen's Union, 1940

LCVA 5 - LCVA, f. 929, ap. 3, b. 1131. Mobilisation directives, 1940

LCVA 6 - LCVA, f. 929, ap. 3, b. 1153. Cover, the $2^{\text {nd }}$ Infantry Division Plan, 1940.

LCVA 7 - LCVA, f. 929, ap. 3, b. 1155. Cover, the $2^{\text {nd }}$ Infantry Division Plan, 1940

LCVA 8 - LCVA, f. 929, ap. 5, b. 547. Mobilisation Communication of September 1939

LCVA 9 - LCVA, f. 929, ap. 5, b. 587. The 1940 Directive for the Mobilisation of Border Guard Troops

LCVA 10 - LCVA, f. 929, ap. 5, b. 605. Correspondence relating to border protection, 1940

LCVA 11 - LCVA, f. 929, ap. 5, b. 608. Correspondence of the Mobilisation Unit of the $3^{\text {rd }}$ Department of the General Staff of Armed Forces, 1940

Gomenyuk I. (2017) The harbinger of the Second World War. Border conflicts in Central and Eastern Europe. From the collapse of empires to Gliwice provocation. Kharkiv: Book club 'Family Leisure Club', 352 p. (ukr).

Efimov G. (2004) The concept of territorial defense is the basis of the State's defense capability. Army of Ukraine. Kiev. No 5-6. P. 13-16. (ukr).

Jokubauskas V. (2012) The Concept of Guerrilla Warfare in Lithuania in the 1920-1930s. BALTIC REGION, no. 2 (12). P. 32-43. (eng)

Kentiy A. V. (1998) Ukrainian Military Organization (UVO) in 1920-1928. Short sketch. Kiev, 81 p. (ukr).

Kuceruk O. (2000) The last Passport of Yevgeny Konovalets (to the genesis of Ukrainian-Lithuanian relations between the two World Wars). Memory of the Ages. No. 5. P. 59-60 (ukr).

Kuceruk O. (2019) Lithuania and Ukraine: Episodes of Common History. Kiev: Iron Dad, 118 p. (ukr).

Martynec W. (1949) The Ukrainian Underground (The Resistance Movement). From U.W.O to O.U.N. (1920-1929). Memoirs and materials. Winnipeg: Ukrainian National Fed'n. D. E., 349 p. (ukr).

Mihailov, A. O. (2013) The role and place of internal affairs of Ukraine in the system of territorial defense of the State. Труди академіï, No 2 (116). P. 121-125. (ukr).

Mirchuk P. 1968. Outlines of the History of the Organization of the Ukrainian Nationalists. Vol. 1. Munich-London-New York: Ukrainian Publishing House, 639 p. (ukr). 
Paliy V. V. 2006. Substantiation of tasks of the Armed Forces of Ukraine in conducting territorial defense. [PhD thesis]. Kyiv, 237 p. (ukr).

Pankratov E. E., Efimenko V. I. 2015. Territorial defense. The Defense Bulletin. Kyiv, No. 11. P. 12-16 (ukr).

Petrik A. M. (2018) "Light and shadows"of the First Republic: The State of Lithuania in 1918-1940. Cherson: Gileja, 272 p. (ukr).

Romanchenko I. S., Frolov. V. S. (2009) The role and place of territorial defense of Ukraine in the whole system of State defense. Science and Defence. Kiev. No. 1. P. 36-39 (ukr).

Saganjuk F., Gumenjuk V. (2011) Territorial defense: the country's defense capability. Army of Ukraine. Kiev. No 6. P. 15-17 (ukr).

Frolov V. S. (2010) Justification of the mechanism for determining the required composition of Military Units of territorial defense in a zone of military conflict. [PhD thesis]. Kiev, 191 p. (ukr).

Yaniuk S. (2019). Territorial defense as a counteraction to the threats of the national security of Ukraine. Actual problems of public administration. Odesa, No. 1 (77). P. 94-99 (ukr).

Dumin O. (1974) The truth about the Ukrainian military organization. Zeszyty historyczne. Paris. Vol. 30. P. 103-137 (pol).

Bulvičius V. (1994) National Military Training. Vilnius: National Defence Volunteer Forces, 274 p. [first edition 1939]. (Lithuanian).

Jokubauskas V. (2009) Faint Possibilities: to Resist Germany's Military Threat in 1939. History, vol. LXXIII. P. 25-36 (Lithuanian).

Jokubauskas V. (2011) Looking into the Future: the spread and realisation of Guerrilla Warfare tactics in Lithuania 1944-1953. Genocide and resistance, No. 1 (29). P. 51-68 (Lithuanian).

Jokubauskas V. (2012a) Lithuania on the threshold of War: 1939 military mobilization. War archive, vol. XXVII. P. 276-332 (Lithuanian).

Jokubauskas V. (2012b) "All Alone": Riflemen Training for the Guerrilla Warfare in Lithuania in 1924-1940. History, vol. LXXXVI. P. 11-24 (Lithuanian).

Jokubauskas V. (2014a) Power of "Small Armies" and Paramilitarism: the Case of Interwar Lithuania. Klaipėda: Klaipėda University, 588 p. (Lithuanian).

Jokubauskas V. (2014b) Plan "R" of the Lithuanian Armed Forces (19391940). History, vol. XCIII, Nr. 1. P. 5-47 (Lithuanian).

Jokubauskas V., Tamkvaitis T. (2018) Two Military History Sources from Interwar Lithuania. In THE UNENDING WAR? THE BALTIC STATES AFTER 1918 = NESIBAIGIANTIS KARAS? BALTIJOS ŠALYS PO 1918 METÜ, Acta Historica Universitatis Klaipedensis, vol. XXXVI. Ed. by V. Jokubauskas, V. Safronovas. Klaipėda. P. 177-242 (Lithuanian).

Jokubauskas V. (2019). An indirect approach and the military safety of Lithuania in 1919-1940. Klaipėda: Druka, 368 p. (Lithuanian).

Kasparavičius A.; Mieliauskas T. (1998) The Lithuanian-Polish Relations and Modernisation of the Lithuanian Armed Forces in 1926-1939. War archive, vol. XV. P. 144-161 (Lithuanian).

Lesčius V. (2004) Lithuanian Army in Liberation Wars 1918-1920. Vilnius: General Jono Žemaitis Military Academy of Lithuania; Vilnius University, 500 p. (Lithuanian). 
Lesčius V. (2013) Plans of Defence and Measures by Lithuanian Army to Repulse the Possible Polish Agression in 1921-1937. War archive, vol. XXVIII. P. 149-304 (Lithuanian).

Lithuanian Riflemen's Union in State and Public Service 1919-2004. (2005) Edit. V. Kavaliauskas, J. Širvinskas, S. Jegelevičius. Kaunas: Lithuanian Riflemen's Union, 312 p. (Lithuanian).

Vaičenonis J. (2002) The Lithuanian Riflemen's Union in the System of National Defence in 1935-1940 m. Fragments of the History of the Lithuanian Riflemen's Union. Conference report materials. Edit. J. Vaičenonis; S. Dovydaitis. Kaunas: Lithuanian Riflemen's Union. P. 110-119 (Lithuanian).

Vareikis V. (1999) The Lithuanian Riflemen's Union Political and Military Activity (1919-1923)]. [Doctoral Dissertation]. Kaunas: Vytautas Magnus University, 145 p. (Lithuanian).

Vareikis V. (2013) Exit from K. Donelaičio Street: Military activity of Lithuanian Riflemen's Association in 1919. Kaunas History Yearbook, t. XIII. P. 147-161 (Lithuanian).

Vygantas. (1933) What does the current agenda tells us. Trimitas, 20 April, 1933, No. 16. P. 301-302 (Lithuanian).

Žalys V. (1989) The Question of the Military Collaboration in the Baltic Entente System (1939-1940). The Year-Book of Lithuanian History 1988. P. 59-78 (Lithuanian).

\section{Jokubauskas V.}

\section{TERRITORIAL DEFENCE IN LITHUANIA IN THE LATE 1930S}

In the interwar years, Lithuania faced a wide range of military threats, for two decades the nation did not maintain any diplomatic or economic relations with its neighbouring state Poland, which had occupied her historic capital Vilnius, while the relations with Germany remained tense over the Klaipeda Region. The security situation took a turn for the worse in 1939-1940 with the threat from the USSR coming to the front after the annihilation of Poland, however Lithuania was forced to sign the mutual assistance treaty and permit the entry of 20 thousand strong Red Army troops into its territory. Hence, a small state of Lithuania was locked in by the hostile states that surpassed her in strength by several or many orders of magnitude. The Lithuanian armed forces were compelled to seek unconventional solutions for the organisation of national defence.

This research, aimed at the identification of measures undertaken by the Lithuanian armed forces for the purpose of the enhancement of its military capabilities and the increase of countermobility facilities as part of its territorial defence system, is based on the analysis of archival sources. The Lithuanian army prepared several operation plans in 1936-1940: No. 1 "V" (Germany), No. 2 "V+L" (Germany + Poland), No. 3 "L" (Poland) and, on the basis of the latter, "R" (The Reds / Russia / The East - the meaning of letter $\mathrm{R}$ is not definite). The documents constituting plan No. 1 "V" (Germany) have been selected for the purpose of the analysis of territorial defence since they have come down to us intact while the 
documents pertaining to plan "R" were destroyed in July 1940. The degree of detail of plan No. 1 "V" (kept at the Lithuanian Central State Archives under f. 929 and f. 561) allows for a highly accurate reconstruction of the development and functionality of territorial defence during the interwar period and of the connections between territorial and regular military units in the event of war.

We can conclude that the Lithuanian army, on the strength of the system of territorial defence (integrated into the overall national armed defence plans) as revealed in our research, hoped to slow down the penetration of enemy forces into Lithuania using these countermobility measures and thereby to "buy" time for the mobilisation and consolidation of its regular forces, whilst the action of guerrilla territorial units in the areas taken up by enemy was supposed to restrict enemy actions and withdraw as many soldiers from the rear zone of the front for protection purposes. In the rear area, the Lithuanian territorial units had to release, to the extent possible, their regular troops from the functions of defence and the maintenance of order. It was expected that defeat would be avoided in the event of war with a more powerful enemy due to the synergy of action of territorial and regular forces. There was a clear understanding that the outcome of the war would be determined not by the Lithuanian armed forces but by the success of the Allies (the cases of Belgium and Serbia in the First World War were regarded as examples for Lithuania in the upcoming war). The objective was to persist and survive, i.e. to preserve the nucleus of military forces and the government and proceed with guerrilla warfare in the occupied territories so that in the wake of an all-out war there would be a basis for the reconstitution of the Lithuanian state within its ethnographic boundaries. 